\title{
Globalising and localising translation strategies from rhetorical perspective: Rendering English headlines into Ukrainian
}

\author{
Serhiy Potapenko ${ }^{* 1}$ \\ ${ }^{1}$ English Philology, Translation and Philosophy of Language Department named after \\ O.M. Morokhovsky, Kyiv National Linguistic University, Kyiv, Ukraine
}

\begin{abstract}
The paper develops an idea of globalising and localising strategies of media text translation in the framework of the rhetorical canons of invention, concerning selection of arguments; disposition, dealing with their arrangement; elocution, aimed at the choice of linguistic units; performance, underlying the formation of different kinds of discourse. The globalising strategy of translation renders the international content into the target language with minor changes in disposition or elocution while the localising strategy adjusts the global content to the worldview of the local readership changing text organisation at particular rhetorical levels. The article discusses the application of the globalising and localising strategies to the translation of the BBC's English online headlines into Ukrainian with respect to their three structural positions: attracting attention by foregrounded units, keeping it by predicative groups, nudging the reader towards the text body in the final position. It is found that Ukrainian translations of English headlines intensify the globalising strategy extending the nudging utterances which compel the reader to turn to the text while the localising strategy is implemented by the techniques of specification or perspectivation altering the disposition of the original headline by foregrounding references to the entities important for the local audience.
\end{abstract}

\section{Introduction}

Strategy is known to be one of the most ambiguous terms in translation theory: it is not only used in different ways, but it is also found to be in competition with a number of other terms such as procedures, techniques, operations, changes, shifts, methods, replacements, etc [1]. Some of them seem to converge when strategies are defined as potentially conscious procedures for solving a problem faced in translating a text, or any segment of it [2]. In the cited definition the difference between translation strategy and procedure can be pinpointed if we turn to the more general idea of communicative strategies. Being embedded into verbal interaction they appear to be akin to translation strategies though with a difference: the participants of regular speech interchange are free to choose the topic and the means of its verbalisation while the translator is restricted by the meaning and form coded in a source language.

\footnotetext{
${ }^{*}$ Corresponding author: potapenkoknlu@gmail.com
} 
The definition of communicative strategies as plans of achieving an addressor's goal [3] reveals their similarity to genre also treated as a goal-oriented temporarily stable, though flexible phenomenon [4] which imposes constraints on the use of lexicogrammatical and discursive resources [5]. Consequently, the application of strategies as goal-oriented entities in communication and translation appears to influence the organisation of a text as a whole at two levels: generic with its more or less fixed goal and stringent requirements; structural, providing for the signal distribution [6] via techniques of combining meanings in ways that will effectively promote communication [7].

The subordination of strategies to genres proves the applicability of the latter former to whole texts unlike procedures or techniques organising separate stretches of speech, either produced or translated. The textual status of translation strategies is supported by the two best known of them: domesticating, involving adherence to local literary canons both in choosing a foreign text and in developing a translation method, and foreignising, seeking to evoke a sense of the alien necessarily answering a home situation, where it may be designed to serve a cultural and political agenda [8]. The application of the two strategies seems restricted to the translation of literary and technical texts with the latter considered fundamentally domesticating since they intend to support research [8]. However, the two strategies fail to explain the ways of translating contemporary English media texts in general and news stories in particular into national languages which is illustrated by the comparison of the headlines introducing the same piece of news on the BBC's two websites: English (https://www.bbc.com/news) and Ukrainian (https://www.bbc.com/ukrainian), cf. Twitter permanently suspends Trump's account Twitter остаточно заблокував аккаунт Трампа (9 Jan 2021). At first glance, the Ukrainian translation of the English headline appears to display three degrees of foreignising: non-assimilation, illustrated by the use of the English word Twitter without any adaptation to the Cyrillic alphabet of the Ukrainian language; partial, exemplified by the unit аккаунт, a Cyrillic transliteration of the English word account; fully assimilated, represented by the proper name Tpamn which phonetically, graphically and grammatically behaves like other Ukrainian words though denotes a foreign politician. This example suggests that in the Ukrainian news discourse the foreignising strategy fails to cover varying ways of rendering English terms and the wide-spread use of the words known as barbarisms: QAnon, Billingcat, Porlab, Covid-19, Abode Flash, Boeing, BBC, Uber etc. Their occurrence in Ukrainian translation seems to perform a practical task of facilitating the identification of the entities widely known by their English names.

English terms in the texts translated into Ukrainian seem to indicate the emergence of the globalising strategy of translation brought about by the world status of English. Their use is not just a matter of adding a foreign flavour but a way of facilitating the identification of the entities known by their English names in the contemporary world. However, globalising is not the only tendency which influences the translation of news, as some researchers claim [9, p. 18]. It interacts with localising which consists in adjusting the international content to the expectations of the regional audience which is wider than adherence to local literary canons presupposed by the domesticating strategy [8]. The differentiation of globalising and localising strategies of translating media texts emerges under the influence of the glocalisation trend of world development which means simultaneous occurrence of both universalising and particularising tendencies in contemporary social, political, and economic systems [10]. The glocalisation predisposition indicates that the translation of news texts from English into national languages depends on the global or regional status of covered events. These relations are illustrated by the following two headlines from the front pages of the BBC's English and Ukrainian sites: Minister who promoted 'Covid syrup' tests positive - Пропагувала шампанський сироп від ковіду: скандальний міністр захворіла (23 Jan 2021). 
According to the localising strategy of translation the Ukrainian headline foregrounds the construction пропагувала шампанський сироп від ковіду "promoted Covid syrup" depicting an unusual sensorimotor activity which is likely to attract the local audience's attention. Meanwhile reference to the minister opening the English headline is moved to the middle of its translated variant to avoid ambiguity with Ukrainian counterparts.

With this in mind, the research question consists in revealing globalising and localising strategies of translating the BBC's English headlines, forming a specific news genre of mini-texts, into Ukrainian. The globalising and localising strategies of translation are reconstructed within the framework of regular communication which prompts the application of the rhetorical approach.

\section{Methods}

The rhetorical method of studying communication in general and translation in particular rests on five traditional canons: invention, concerning the selection of arguments; disposition, dealing with their arrangement; elocution, aimed at the choice of linguistic units; memory and delivery [11] merging into performance which underlies the emergence of media discourse formed by modern technologies. This separation of canons mainly serves research and educational purposes though in communication they are inseparable: at the stage of invention the author and the translator alike are already aware of the content arrangement at disposition and vocabulary choice at elocution; the dispositional level is restricted by the content selected at invention and possibilities of elocution in a particular language; the elocution level is subordinated to invention and disposition.

At the level of invention the choice of a news topic is determined by the human needs: physiological, concerning an individual's existence; safety, related to security; belongingness, meaning being part of a group; reputation, linked to the respect of society; self-actualisation, connected with people's development [12]. The most important need for the organisation of media discourse in general and of its news type in particular is belongingness: in terms of glocalisation it sees the recipient's being part of both the world at large and of a separate speech community covered by a site in a particular language.

At disposition, news discourse forms three sublevels impacting both speech production and translation: hypertext, i.e. a non-linear organisation of media material; macrocomposition, concerning the arrangement of a text as a whole; micro-composition, covering the structure of headlines and individual paragraphs which in modern news discourse tend to be expressed by separate utterances forming sentential paragraphs. The structure of headlines sandwiched between hypertext and text body depends on both of them. While the macro-composition of a text is meant to sustain the reader's attention, the production and translation of headlines are influenced by their main functions deriving from three internal positions: first, they attract the addressee's attention foregrounding units referring to entities close to the target audience; second, they keep the reader's attention by the units in the predicative position characterising the referent named initially; third, the final component of a headline nudges the addressee to turn to the text body, cf. Climber described 'killer Mountain' ordeal - Врятована альпіністка: галюциначії та босоніж nо снігу (1 Feb 2018). In the English headline the foregrounded noun climber attracts the recipient's attention, the predicate described keeps it and the 'killer Mountain' ordeal construction nudged the reader towards the text body since the noun ordeal refers to severe experience which is likely to compel the addressee to read the news. The Ukrainian translation of the English original consists of two components distributing the recipient's attention: the construction врятована альпіністка "saved climber" attracts it evoking the safety need while the component галюцинаціï та босоніж по снігу nudges the reader 
towards the text body exemplifying the ordeal by more concrete phenomena of hallucination and barefoot walk on the snow.

Elocution determines the choice of linguistic units denoting particular referents with an eye on attracting, keeping and nudging the recipient's attention in headlines and sustaining it in the text. This level of translating the headlines under discussion seems more emotional than the original: the English variant foregrounds the neutral noun climber followed by the units killer and ordeal evoking the emotion of fear together with the security need while all the constructions in the translation trigger those emotion and need.

In case of translation the application of the rhetorical stages of analysis alters except the discourse type and genre belongingness which remain stable due to their connection with the performance level.

The translation analysis is carried out in terms of referential content, i.e. the equivalence between the entities denoted in the source and target languages, which is either imposed on the translator or chosen at the level of invention. Disposition, determining the structure of a target text, is predetermined in case of translation at the macro-level though changeable at the micro-level of headlines and sentential paragraphs. Elocution seems to be more or less free for the translator though as the comparison of the headlines above suggests some features of the original are to be projected onto the target piece.

This paper explains the rendering of headlines from English into Ukrainian within the framework of rhetorical canons of invention, disposition, elocution and performance which can be applied both to production and translation of texts.

At the level of invention the referential content encoded in the headlines in English and Ukrainian is analysed drawing on the linguistic units referring to the entities connected with the human needs embedded in the global or local worldview.

At the micro-dispositional level the distribution of the referential content is related to the headline positions of attracting, keeping and nudging the recipient's attention.

Elocution subordinates the use of linguistic units with regard to the global or local status of the audience and their needs as well as the structure of headlines in terms of attention distribution.

The suggested rhetorical method starts with distinguishing globalising and localising strategies through comparison of the referential content and its distribution in the original headline and its translation: the former strategy signals the equivalence of meaning and structure while the latter presupposes differences in the content patterning.

The equivalence of the referential content and structure of the two headlines below testifies to the use of the globalising strategy of translation, cf. Uber halts self-driving car tests after death - Uber зупиняє випробовування безпілотного автомобіля після загибелі людини (19 Mar 2018). At the invention level both the original and the translation appeal to the self-actualisation need evoked by the proper name Uber, referring to a global company, and safety need, triggered by information about the halt of the tests after an individual's death. The dispositions of the headlines in the two languages turns out to be similar, too: the unit Uber is foregrounded both in the original and in the translation to attract the addressee's attention; the predicative groups halts self-driving tests in English and its equivalent зупиняє впровадження безпілотного автомобіля in Ukrainian keep the reader's attention characterising the company's activities; the referentially equivalent constructions after death and після загибелі людини nudge the addressee towards the text body. The elocutionary stage of analysis reveals the use of the English noun Uber in the translation so as to underscore the global status of the company with other linguistic units displaying no specific meaning.

The localising strategy of translation reveals more differences between original and translation which is demonstrated by the comparison of the following two headlines in 
English and Ukrainian: Husband on leash breaches Quebec's Covid curfew - Жiнка вигулювала чоловіка на повідку, щоб обійти комендантську годину (12 Jan 2021).

Though the referential content of the headlines in English and Ukrainian seems equivalent there is a major difference at the inventive level: the predicate breaches in the original points to the consequences of the walk described while the predicate вигулювала "was walking" in the translation refers to the stroll proper. The reasons for that seem to derive from differences in the goals of the two headlines: the original locates the event on a particular territory denoted by the place name Quebec while the translation focuses on the anecdotal nature of the happening with no reference to the location.

The disposition of the original and its translation is reflected in the distribution of the lexical units with respect to attracting, keeping and nudging the recipient's attention. The foregrounding of the units in the original and in the translation indicates a change in the perspective of event representation: the headline in English portrays the content from the point of view of a husband performing the role of a dog while the Ukrainian variant depicts it from the viewpoint of the wife acting like a master.

Elocution concerns the choice of the units filling in the three attention-related positions of the original headline and its translation. Both attract the recipient's attention appealing to the need of belonging to the family though from opposite perspectives: those of husband and wife. The headline in English keeps the reader's attention by the verb breach evoking safety need by focusing on law violation while the translation sustains it by the verb вигулювала "was walking" likening the husband to a dog and imparting the content with additional connotations. The headlines in both languages nudge the reader's attention towards the text body by reference to the curfew by specific linguistic units.

With respect to the localising strategy of translation the comparison of the two headlines reveals three transformations: the replacement of consequence with cause at the level of invention; attention attraction by a change of roles within a family and switching attentionkeeping from safety to entertainment at the level of disposition; the changes in invention and disposition determine the alterations in elocution.

The analysis of the examples above proves the applicability of the rhetorical approach to the study of the globalising and localising strategies of translating news headlines from English into Ukrainian.

\section{Research Results}

The application of the rhetorical methods to translation reveals either equivalence or transformation of the original headlines at the levels of invention, disposition and elocution with a fixed genre and discourse type in case of performance. However, the globalising strategy produces different degrees of near-equivalence in Ukrainian headlines due to the extending elements used in the nudging position to compel the local recipient to read a text with international referential content.

\subsection{Modifying techniques implementing the globalising strategy of translation}

The globalising strategy of translation into Ukrainian has extended variants implemented by adding nudging components of sentential status to urge the recipient to read the text. They are expressed by additional utterances missing in the original, cf. Trump congratulates Putin over election - Tрамn привітав Путіна: "Ми дуже добре поговорили" (20 Mar 2018). The two headlines differ in their nudging components: the construction over election from the original is replaced with the utterance ми дуже добре поговорили "we had a nice talk" with a more intense compelling potential since it urges the addressee to turn to the text for the information about the talk between the two presidents. 
The extended generalising strategy of translation implemented by additional affirmative sentences specifies information left out in the English headline or relates it to the state of things in Ukraine against the global background offered by the original, cf. Covid: EU starts mass vaccination in 'touching moment of unity' - ЄC починає вакцинацію від Covid-19. А що Україна? (27 Dec 2020). The comparison of the headline in English and its translation into Ukrainian reveals differences in equivalence at the levels of disposition and elocution: the headings in both languages consist of two utterances but of a different kind. The original attracts the recipient's attention by the unit Covid referring to a global threat while the translation foregrounds the abbreviation $E C$ "EU" denoting the goal of the country's future development. The nudging components also differ: the original refers to Europe's touching moment of unity while translation queries the actions of Ukraine in this way compelling the local recipient to read the text.

The nudging components of the Ukrainian variants of headlines also offer more specific information meant to urge the local reader to turn to the text, cf. Coronavirus spreads to Antarctic research station - Коронавірус дістався останнього континенту. B Антарктиді захворіли 36 полярників (22 Dec 2020). At the level of invention the content of the two headlines seems more or less equivalent with the Ukrainian translation nudging the reader towards the text by an utterance referring to the number of sick people: $B$ Антарктиді захворіли 36 полярників. At the level of elocution the translation emphasises reference to the same territory by two units, namely, останній континент "last continent" and Антарктида "Antarctica".

Nudging questions compel recipients of translated headlines to turn to the text for an answer, cf. Bitcoin tops \$34, 000 as record rally continues - Біткоїн побив рекорд $\$ 30,000$. Чи довго триватиме зростання? (3 Jan 2021). The comparison of the headlines in English and Ukrainian reveals two peculiarities of translation. First, in the original and translation the attention-keeping positions are filled in with different figures: $\$ 34,000$ and $\$ 30,000$ respectively. The original gives a real number while the translation indicates the milestone of $\$ 30,000$ though the text in Ukrainian also refers to the $\$ 34,000$ figure: $A \quad 3$ січня вартість біткоӥна зросла до 34000 доларів (https://www.bbc.com/ukrainian/news-55520751). The difference seems to depend on the number of the members of audience interested in the crypto-currency worldwide and locally: the former constitute the majority in need of exact figures while few Ukrainians are engaged in that sphere of activity. Second, the nudging component of the English original refers to a new period of currency strengthening while the Ukrainian translation questions its future arousing the local people's interest.

Some of the extending techniques discussed above are employed to implement the localising strategy along with other procedures.

\subsection{Techniques implementing the localising strategy of translation}

The localising strategy of translation adapting the global referential content from the English site to the mindset and needs of the Ukrainian audience is implemented by the techniques of specification, generalisation and perspectivation with several variants.

\subsubsection{Techniques specifying and generalising the content of the original headlines}

The techniques specifying the referential content of the original headlines are implemented in four ways: inserting place modifiers, foregrounding them, interlanguage hyper-hyponymic transformations and more concrete metonymy in Ukrainian variants.

Place modifiers as a means of specification are inserted into the translations of the English headlines about physical and social phenomena distant from Ukrainians, for 
example, the death of whales and MeToo movement. The English headline has no reference to the place where the whales perished while the translation points to Australia: Over 100 whales die in mass stranding - В Австралії на берег викинулися 150 дельфінів (23 Mar 2018). At the level of disposition the translation foregrounds the adverbial modifier 6 Австралії "in Australia" moving the construction referring to the number of the dead animals to the nudging position. Two transformations occur at the elocutionary level: first, the figure 100 is replaced with 150 reflecting an increase in the number of dead animals while the piece of news was being prepared for the Ukrainian site; second, the noun whales in the original is replaced in the translation with дельфіни "dolphins", referring to the animals popular in different kinds of local entertainments: the change seems well-grounded since the dead animals belong to the oceanic dolphin family.

The translation of an English headline about a distant social phenomenon concerns the MeToo movement, cf. Actor found dead after MеТоo claims - Південна Корея: актора, якого звинуватили в домаганнях, знайшли мертвим (9 Mar 2018). With respect to disposition the original headline foregrounds the noun actor, keeps the reader's attention by the predicate found dead and nudges him/her to the text body by reference to the MeToo movement. Conversely, the translation attracts the recipient's attention by reference to South Korea while the actor is identified in the attention-keeping position. At the level of elocution the MeToo movement, which is far from popular in Ukraine, is interpreted by the noun домагання referring to harassment.

The place modifier is foregrounded in the Ukrainian headline from the nudging position of the original when it is more likely to attract the local audience's attention: Metal monolith found by helicopter crew in Utah desert - У пустелі Юти знайшли таємничу металеву стелу (24 Nov 2020). While the original grabs the audience's attention by the construction metal monolith the translation refers to a desert where the object was found since a place like this is more exotic for the Ukrainian recipient. Moreover, reference to a metal monolith by the phrase металева стела in the nudging position seems more appropriate since it urges the reader to turn to the text for additional information about the mysterious object.

The hyper-hyponymic interlanguage transformations rest on the following relations: gender - profession, cf. French woman flown from 'Killer Mountain” - Франиузьку альпіністку врятували з "гори-убивичі» (28 Jan 2018); container - content, cf. NagornoKarabakh: The families burning down their own homes - Чому вірмени спалюють свої будинки і тікають з Карабаху (15 Nov 2020). The last headline in English foregrounds the unit Nagorno-Karabakh to refer to a contestable territory known worldwide while in this position the Ukrainian translation names Armenians, i.e. its contents. Moreover, both headings have an implicit nudging structure compelling the addressee to turn to the text body: the original rests on a paradox describing people burning down their houses while the interrogative form of the Ukrainian version implies that the text may give an answer.

Metonymy employed in the Ukrainian translations of English headlines is more concrete than in the original which is brought about by the global and local status of the two BBC sites, cf. China derides Cold War US nисlear plan - Пекін засудив ядерний план США «часів холодної війни» (4 Feb 2018). In the English original the Chinese authorities are indicated by the country's name to attract the attention of the global audience but in the translation they are pointed to by the name of the state's capital. Metonymic interlanguage transformations include the following patterns: country - a body of power, cf. China proposes - Китайська компартія пропонує (25 Feb 2018); country - its military, cf. Syria takes half of rebel-held enclave - Сили Асада захопили половину Східної Гути (7 Mar 2018); country - its leader, cf. North Korea invites South president for visit - Kiм Чен Ин запросив президента Південної Кореї у Пхеньян (10 Feb 2018). The dispositional country - its leader metonymic transformation is represented by the following pair of 
headlines: Highly likely Russia behind attack-UK - Тереза Мей: Скрипаля отруїли речовиною, розробленою в Росї (12 Mar 2018). In the cited example the interlanguage metonymy UK - Тереза Мей "Theresa May" is accompanied by foregrounding the British Prime Minister's name in the Ukrainian headline.

The generalisation of the original referential content is designed to meet the needs of the majority of the local readership, cf. Stockholm mother arrested 'after keeping son for decades in flat' - Жінка 30 років не випускала з дому сина. Полічія з'ясовує, як ие трапилося (2 Dec 2020). To attract the local audience's attention the translation removes reference to Stockholm where the event took place, foregrounds the noun жінка "wотаn" instead of mother, replaces the recency order of events which begins with the latest with a chronological sequence referring first to the crime and then to police's actions.

Ukrainian translations of English headlines combine generalisation with distancing achieved by deleting emotives, cf. Slovakia shocked by journalist's shooting - $y$ Словаччині знайтли мертвим 27-річного журналіста (26 Feb 2018). The Ukrainian headline weakens the attention-keeping position replacing the verb shock denoting emotions with the unit знайшли "found" referring to perception. However, the translation strengthens the nudging position additionally naming the age of the assassinated journalist.

\subsubsection{Techniques of perspectivational switch}

The perspectivational switch occurs at the levels of disposition and elocution due to foregrounding references from the attention-keeping position of the original into the attention-attracting slot in the translation.

The following types of switch between the original headline and its translated variant occur: personal name - common noun; common noun - personal name; name of a person his / her quotation; personal name - name of an organisation; name of an affected country name of a source country.

The personal name - common noun switch between the original and the translation is aimed at introducing an individual to the Ukrainian audience by reference to his / her profession, cf. Zhang Zhan: China jails citizen journalist for Wuhan report - Журналістку ув'язнили на чотири роки за репортажі з коронавірусного Уханю (28 Dec 2020). The dispositional difference between the headlines in the two languages consists in rendering a two-utterance English heading by a one-utterance variant in Ukrainian. The distinction in elocution is reflected in foregrounding the journalist's full name in the original to raise her status and the noun журналістка "journalist" referring to her profession in the translation while the reader's attention is kept by the construction yв'язнили на чотири роки "sentenced to four years" underscoring the Chinese authorities' unfairness. However, the referential content of the nudging components is equivalent being expressed by the constructions for Wuhan report in the original and за репортажі з коронавірусного Уханю in the translation.

The common noun - personal name transformation provides for the switch from a general - global - perspective to the local view of the referential content. The choice of the foregrounded units in the translation depends on the popularity of a named person with the local readership, cf. Russian agent is 'tricked into detailing Navalny assassination bid' Навальний додзвонився до ймовірного учасника отруєння. Той розповів деталі onepauiï (21 Dec 2020). The English original and its translation demonstrate differences in attracting the recipient's attention by reference to a despised Russian agent and the country's outstanding opposition figure respectively. Though in the original the nudging component is expressed by the phrase assassination bid the translation uses a separate utterance intensifying the urge to read the text: Той розповів деталі операиіï "That one told about the details of the operation". 
The name of a person - his / her quotation switch renders speech activity of foreign politicians or pop stars creating an impression of authenticity.

The switch of this kind is represented by the following pair of headlines about President Putin's press conference: Russia's Putin calls Navalny poisoning inquiry 'a trick' - Tрюк, американські спеислужби, кому він треба - що Путін розповів про Навального (17 Dec 2020). The headline in English foregrounds Putin's name, keeps the reader's attention by the predicative group calls Navalny poisoning inquiry and nudges the addressee to the text body by the noun trick. Conversely, the translation attracts the recipient's attention by the noun трюк "trick" nudging him/her to the text by the clause щцо Путін розповів про Навального "what Putin told about Navalny". A switch of this kind is also employed in the translation of a headline about a famous American movie star - Tom Cruise: Recording emerges of star 'shouting at film crew' over Covid - "Побачу таке знову - вас тут нема". Том Круз накричав на знімальну групу через коронавірус (16 Dec 2020). The original headline attracts the recipient's attention by the personal name Tom Cruise, keeps it by the construction recording emerges serving as an argument for the nudging expressed by the word combinations describing his rude language: 'shouting at film crew' over Covid. Meanwhile the translation foregrounds the nudging component of the original so as to attract the local audience's attention at the sensorimotor level which endows the headline with authenticity: Побачу таке знову - вас тут нема "If I see anything like this again you won't be here."

The personal name - name of an organisation switch is determined by differences in the reputation of denoted entities worldwide and locally, cf. Alexei Navalny: Report names 'Russian agents' in poisoning case - Billingcat назвала ФСБешників, які стежили за Навальним в день отруєння. Серед них були лікарі (14 Dec 2020). The original headline attracts the global audience's attention by the personal name Alexei Navalny referring to the leading opposition figure in Russia while the translation foregrounds the name of the Billingcat organisation, well-known in Ukraine due to its investigations into Russian subversive activities. Against this background the attention-keeping components refer to the Kremlin emissaries by the constructions Russian agents in the original and ФСБешники "FSB employees" in the translation. In the Ukrainian headline the nudging component is intensified by the additional utterance Серед них були лікарі indicating that there were doctors among the poisoners which compels the recipient to find out more information about them in the text.

The name of an affected country - name of a source country switch mainly characterises the translation of headlines about Russia: its name is usually found in the attentionattracting positions on the English site being moved to the attention-keeping slots in the Ukrainian variants which foreground the units referring to the sources whose activity is leveled against Russia, cf. Russian military helicopter downed in Armenia - Азербайджан збив російський гелікоптер у Вірменії (9 Nov 2020), or to their location, cf. Russian fighter jet shot down in Syria - У Сирії збили російський літак (3 Feb 2018). The perspective offered in the Ukrainian headlines seems more objective than in the English originals: in the translation the verbs in the active voice name the source of an action, i.e. Azerbaijan, or its position, i.e. Syria, before the target, reflecting the natural order of events while in the original the verbs in the passive indicate special attention to Russia as a target of activity.

Similarly, for the sake of attracting the global attention the Russian president's name is fronted in the English original headlines, cf. Putin blamed for attack on ex-spy Skripal Британія: рішення отруїти Скрипаля 'иілком імовірно' приймав Путін (16 Мar 2018). Unlike the English headline foregrounding the personal name Putin the Ukrainian variant attracts the recipient's attention by the place name Британія "Britain" referring to a country enjoying a higher status than Russia. The attention-keeping constructions blamed 
for attack and рішення отруїти Скрипаля 'иілком імовірно' приймав are approximately equivalent though the Ukrainian variant seems more detailed while the nudging components in the two headlines refer to different individuals: the original names ex-spy Skripal and the translation indicates President Putin.

The headlines translated into Ukrainian render Russian president's low media status foregrounding the lexical units emphasising his derogatory characteristics, cf. Obama memoir: what he really thought of Putin and other leaders - «Вуличний барон»: щ⿻ написав Обама про Путіна та інших лідерів світу (20 Nov 2020). At the dispositional level the cited English headline and its translation differ in the position of the name of the former American President Obama. In the original it is foregrounded to attract the global audience's attention while in the translation it keeps the reader's attention which is attracted instead by foregrounding the derogatory reference to the Russian president by the phrase вуличний барон "ward boss". This word combination occurs only in the lead of the English news story meant for the global audience: Former US President Barack Obama likens Russia's Vladimir Putin to a tough Chicago "ward boss" (https://www.bbc.com/news/world-us-canada-55009571).

The Ukrainian versions of headlines attract the audience's attention by foregrounding the names of locally notorious figures which is the case with Adolf Hitler, cf. Namibia: Man named after Adolf Hitler wins local election - Адольф Гітлер переміг на виборах в Hамібii (3 Dec 2020). The distinction in the disposition between the original and its translation results from the difference in the familiarity of the intended readership with the concepts indicated in the attention-attracting positions. In the original the foregrounded place name Namibia performs an identifying function for the global audience while in the translation the personal name Адольф Гітлер "Adolf Hitler" refers to the Ukrainian people's infamous enemy. The attention-keeping component of the original (man named after Adolf Hitler) is longer since it gives information both about the winner of local elections in an African country and his ill-famed namesake. The nudging slots are filled in differently: the original refers to local election emphasising the man's ties with Namibia indicated in the foregrounded position while the translation names voting by the phrase вибори в Намібіі.

\subsubsection{Techniques of emphatic perspectivational switch}

The switch of perspective is often accompanied by emphasis on particular referents by adding in the translation units denoting quantity or by the adjectives raising the status of denoted entities.

Quantity is usually underscored in translation by numeric expressions which in the original occupy the attention-keeping position, cf. Covid: Denmark to dig up millions of mink culled up over virus - Мільони вбитих данських норок викопають $і$ спалять (21 Dec 2020). As can be seen, the English headline attracts the recipient's attention to the safety need by the noun Covid, keeps it by the construction to dig up millions of mink and nudges it by the phrase culled up over virus. The translated headline consists of two components: it attracts the recipient's attention by the numeric expression мільони "millions" and keeps it by the predicates викопають "will dig" and спалять "will burn". In other words, the attention-keeping reference of the original is shifted to the nudging position of the translation compelling the reader to turn to the text. Strange to say, the Ukrainian headline has no reference either to the pandemic or to the virus indicated in the original.

The use of the noun кількість "number" and the word combination реальна кількість "real quantity" in the translation is linked to the inventional level since the named concepts are not even implied in the original. In such cases the idea of quantity is underscored by 
foregrounding the noun кількість "quantity", cf. Plane crash deaths rise in 2020 despite Covid pandemic - Кількість жертв авіакатастроф у 2020 зросла попри Covid-19 (2 Jan 2021), or the word combination реальна кількість "real quantity", cf. Russian Covid deaths three times the official toll - Реальна кількість смертей через Covid-19 у Росії втричі більиа за офіиійну (29 Dec 2020).

The translation raises the status of denoted entities by the modifiers легендарний "legendary", рідкісний "rare", унікальний "unique", перший "first" subordinated to the inventive, dispositional-elocutionary or elocutionary techniques of translation. According to the inventive technique the translator refers to the entities which are not indicated in the original; the dispositional-elocutionary technique foregrounds units altering reference; the elocutionary technique is based on the interlanguage synonymy.

The inventive technique of translation is illustrated by an example foregrounding the adjective рідкісний "rare", cf. Reptiles smuggled from Mexico found at German airport stitched inside dolls - Рідкісних рептилій зашили в ляльки і хотіли перевозити контрабандою (3 Dec 2020). In addition to the foregrounded modifier рідкісний "rare", the translation replaces the original recency order of events with chronological portraying it from different participants' perspectives: from customs officers' implied in the original by the verb found and from smugglers' indicated in the translation by the predicates зашили "sewed" and хотіли перевозити "wanted to smuggle."

The dispositional-elocutionary technique of translation is implemented by foregrounding the units легендарний "legendary" to characterise Neverland, cf. Michael Jackson: Neverland Ranch 'sold to billionaire for \$22 m' - Легендарне ранчо Майкла Джексона продали. Але набагато дешевше, ніж хотіли (25 Dec 2020); and by the numeral периий "first" to render the meaning of the adjective only from the original, cf. Lisy Montgomery: Only woman on US federal death row to face execution - Перша за 70 років “федеральна" страта жінки у США відбудеться попри все. Чим вона завинила? (2 Jan 2021). The last example of an emphatic perspectivational switch rests on the replacement of a woman's name used in the original with the construction nерша за 70 років “федеральна" страта жінки у США representing the event in the translation from the historical perspective with the nudging components expressed by a question inquiring about the essence of her crime.

The elocutionary technique based on the interlanguage synonymy is demonstrated by the use of the modifier унікальний "unique" to render the meaning of the attribute only from the original, cf. World's only known white giraffe fitted with tracker to deter poachers - Унікального білого жирафа рятують від браконьєрів. Усіх його родичів вбили (18 Nov 2020). Besides intensifying the attention attracting position by the adjective унікальний "unique" the translation adds a nudging utterance усіх його родичів вбили informing about the slaughter of all its relatives.

\subsubsection{Techniques of reputational re-perspectivational switch}

The reputational re-perspectivational switch is evoked by the translation of the English headlines about famous people's deaths. Headings of this kind consist of two slots in both languages: attention-attraction and nudging. However, they are filled in by units with opposite references: the English headlines underscore the status of the deceased foregrounding their names modified by the units stressing their distinctions, cf. French fashion icon Givenchy dies - Помер франиузький модельєр Живанші (12 Mar 2018), or by common nouns referring to their occupations, cf. Hacker who gave up Wikileaks source dies - Помер хакер, який видав інформатора Wikileaks (16 Mar 2018). As the cited examples suggest, the Ukrainian variants foreground the verb помер 'died' evoking the 
physiological need which means that the BBC's translators are in need of more variegated techniques to render the high status of late individuals.

Sometimes Ukrainian headlines do stress reputation of the deceased: Tribute paid to 'inspirational' Hawking - Стівен Гокінг: відкриття, щсо зробили його відомим (14 Mar 2018). In the cited example the English original attracts the recipient's attention by the noun tribute and nudges it by the scientist's name while the translation grabs the audience's attention by the researcher's full name Стівен Гокінг and nudges it by reference to his outstanding discoveries: відкриття, щзо зробили його відомим.

Similar translation techniques render the referential content of the English headlines about the murders of important people, cf. Top Iranian nuclear scientist assassinated Вбили «батька іранської ядерної бомби» (27 Nov 2020). The two-component headlines in English and Ukrainian differ in the units used in the attention-attracting and nudging positions: the original foregrounds the construction top Iranian nuclear scientist which raises the status of the assassinated researcher evoking the reputation need while the verb вбили "killed" fronted in the translation emphasises the safety need with the nudging component appealing to reputation by the metaphor батько іранської ядерної бомби "father of the Iranian nuclear bomb".

The Ukrainian translations with referential content of this kind do not seem equivalent to the original because of the needs appealed to which should be taken into account by the BBC's Ukrainian office.

The results presented above are important for the translation studies in general and pave the way for unraveling strategies and techniques rendering English news texts into Ukrainian.

\section{Discussion}

Hopefully, the paper proves that production and translation of texts rest on similar principles though with a difference which testifies to the importance of the phenomena of discourse, genre, strategy for both types of speech activity. Consequently, the article applies strategies to explaining the translation of headlines as a specific genre of the news type of media discourse.

The affinity between production and translation allows to render texts into other languages with application of the rhetorical canons of invention, disposition, elocution and performance with the latter forming the basis for the emergence of contemporary media discourse.

The headline content selected at the level of invention appears to be imposed in case of production and translation within the media discourse but differently: in the former case it is the reality that foists it and in the latter case it is the source text. Strictly speaking, the translation of media headlines is subordinated to two strategies: globalising, rendering similar referential content and its distribution in the original and translation, and localising, aiming at the specific needs and outlook of the target audience. The main differences between the globalising and localising strategies are reflected in the disposition of the referential content. Its patterning in the original and translated headlines is linked to their three main positions based on the universal principles of perception: first, headlines attract the recipient's attention, second, keep it, third, nudge the reader to turn to the text body for full information. The three headline positions underlie the techniques applied to implement the translation strategies discussed in this paper. The globalising type is modified by adding a sentential nudging component to the translated headline so as to intensify the reader's compulsion to turn to the text body. The localising strategy is implemented by the techniques aimed at adapting the original content to the local audience's worldview and needs at the levels of disposition and elocution. The specifying 
techniques insert place modifiers, foreground them, use interlanguage hyper-hyponymic transformations and more concrete metonymy. The perspectivational technique is implemented by foregrounding references from the attention-keeping position of the original while the emphatic perspectivational technique additionally emphasises the foregrounded units by numerical expressions or adjectives raising the status of the denoted entities. Reputational re-perspectivation is evoked in headlines about famous people's deaths by a shift from the reputation need in the original to physiology in the translation.

The application of rhetorical techniques to translating English headlines into Ukrainian on the BBC's site reveals several peculiarities. The extending technique modifies the implementation of the globalising strategy to urge the recipient to read the text about the phenomena foreign to him. The specifying technique is meant to adjust the information about the entities distant from Ukrainians by generalising the information pertinent to other countries to involve the local readership. Perspectivational techniques foreground the units referring to the entities close or well-known to Ukrainians while reputational reperspectivation replaces reference to the esteem features of the original with the units evoking the physiological need.

Two general tendencies of rendering headlines from English into Ukrainian strike as unusual: appeal to the sensorimotor experience of the local audience by foregrounding direct speech utterances or by reference to individuals' physical activity to reach the effect of immediacy as well as the use of a narrative order of events instead of the recency sequence employed in the English original.

\section{Conclusion}

The paper finds that English headlines as a news genre are rendered into Ukrainian with application of two main strategies: globalising, rendering international content with little change in reference or structure of the original headings, and localising, adjusting the international referential content to the worldview and needs of the national audience. The analysis of the techniques implementing these strategies in the framework of the rhetorical canons of invention, disposition, elocution and presentation reveals three headline positions sensitive to their production and translation: first, attracting attention by foregrounded lexical units, second, keeping it, third, nudging it towards the text body. The globalising strategy is modified by adding a sentential nudging component so as to push the reader towards the text body. The localising strategy subordinates a number of techniques adjusting the non-familiar referential content to the local people's worldview and needs: referential specification, carried out by inserting or foregrounding place modifiers; interlanguage hyper-hyponymic transformations; more concrete metonymy in the Ukrainian headlines; perspectivation, implemented by foregrounding references from the positions keeping the reader's attention in the original; emphatic perspectivation, emphasising reference of the foregrounded units by numerical expressions or adjectives raising the status of denoted entities; reputational re-perspectivation, evoked by a shift from esteem in the original to the physiological need in translation.

Further investigation in this direction concerns the study of the role of the globalising and localising strategies of translation from rhetorical perspective in rendering news stories and media texts of other genres as well as distinguishing collective and individual voices [13, p. 340] in translating news. 


\section{References}

1. Y. Gambier, Handbook of tr. studies, Vol. 1, 412-418 (https://www.benjamins.com/online/hts/articles/tra7, 2010).

2. W. Lörscher, Translation performance, translation process and translation strategies (Guten Narr, Tuebingen, 1991).

3. R. Wodak, The discourse of politics in action (Palgrave, Macmillan, London, 2011).

4. H. Gruber, Analyzing genres in political communication, 29-72 (John Benjamins, Amsterdam, 2013).

5. V. Bhatia, The Routledge handbook of discourse analysis, 239-251 (Routledge, London and New York, 2014).

6. R. Langacker, Cognitive and communicative approaches to linguistic analysis, 21-60 (John Benjamins, Amsterdam, 2004).

7. J. Davis, Cognitive and communicative approaches to linguistic analysis, 155-176 (John Benjamins, Amsterdam, 2004).

8. L. Venuti, Routledge encyclopedia of translation studies, 240-243 (Routledge, New York, 2001).

9. E. Bielsa, S. Bassnet, Translation in global news (Routledge, London, 2009).

10. J. Blatter, Encyclopedia Britannica, Glocalization (https://www.britannica.com/topic/glocalization, 3 Feb 2021).

11. M. Burke, Topics in Linguistics 17 (1), 1-16 (https://content.sciendo.com/view/journals/topling/17/1/article-p1.xml 2016).

12. A. Maslow, Motivation and personality (Harper \& Row Publishers, New York, 1970).

13. E. Brems, J. McMartin, Literary translation in periodicals, 331-346 (John Benjamins, Amsterdam, 2020). 